\title{
Gamma radiation treatment applied to microbial decontamination of products derived from eggs collected from the retail market in São Paulo
}

[Tratamento por radiação gama aplicado na descontaminação microbiana de produtos derivados de ovos coletados no mercado varejista da cidade de São Paulo]

$$
\text { S. Aquino }{ }^{l} \text {, C.C. } L u i^{2} \text {, B. Corrêa }{ }^{3}
$$

\footnotetext{
${ }^{1}$ Programa de pós-graduação - Universidade Nove de Julho - Gestão Ambiental e Sustentabilidade - São Paulo, SP ${ }^{2}$ Universidade Nove de Julho - Departamento de Ciências da Saúde II- São Paulo, SP

${ }^{3}$ Universidade de São Paulo - Instituto de Ciências Biomédicas II- São Paulo, SP
}

\begin{abstract}
The quality of products derived from eggs depends on the quality of the raw material source and the industrial production. The contamination by fungi and bacteria can occur after exposure of the product in the retail market. The objective of this study was to evaluate the microbiological quality of 60 samples of derivated egg products and evaluate the effects of gamma radiation of cobalt-60, using the dose of 5 and $10 \mathrm{kGy}$, for decontamination of products collected in the retail market in the São Paulo city. The bacterial count was performed by the most probable number (MPN) and the fungal counts by serial dilution after plating surface. It was observed a decrease in the humidity and water activity $(A w)$ values of irradiated whole egg powder and white egg powder samples $(\mathrm{p}<0.05)$, but there was no significant change in the $\mathrm{pH}$ of the same samples irradiated with 5 and $10 \mathrm{kGy}(\mathrm{p}>0.05)$. In the powdered yolk the values of $\mathrm{pH}$ and $A w$ presented a significant difference $(\mathrm{p}<0.05)$, but no significant difference in the humidity values of 5 and $10 \mathrm{kGy}$ irradiated samples $(\mathrm{p}>0.05)$. Effective microbial sterilization of all products occurred at the dose of $10 \mathrm{kGy}$.
\end{abstract}

Keywords: bacteria, sterilization, fungi, irradiation, powdered egg

\section{RESUMO}

A qualidade dos produtos derivados de ovos depende da qualidade da matéria-prima e da produção industrial. A contaminação por fungos e bactérias pode ocorrer após a exposição do produto no mercado varejista. O objetivo deste estudo foi avaliar a qualidade microbiológica de 60 amostras de derivados de ovos e avaliar os efeitos da radiação gama de cobalto-60, utilizando-se as doses de 5 e $10 \mathrm{kGy}$, para descontaminação dos produtos coletados no mercado varejista da cidade de São Paulo. A contagem bacteriana foi realizada pelo número mais provável (MPN), e as contagens fúngicas por diluição seriada em plaqueamento de superfície. Foi observada uma diminuição dos valores da umidade e da atividade de água (Aa) das amostras irradiadas de ovo integral em pó e clara em pó ( $p<0,05)$, mas sem alteração significativa do $\mathrm{pH}$ nas mesmas amostras irradiadas com 5 e $10 \mathrm{kGy}$ (p>0,05). Em gema em pó, observou-se diferença significativa $(p<0,05)$ nos valores de $\mathrm{pH}$ e Aa, mas não houve mudança expressiva nos valores de umidade nas amostras irradiadas com 5 e $10 \mathrm{kGy}(\mathrm{p}>0,05)$. A esterilização microbiana eficaz de todos os produtos ocorreu com a dose de $10 \mathrm{kGy}$.

Palavras-chave: bactérias, esterilização, fungos, irradiação, ovo em pó

\section{INTRODUCTION}

The search for new forms of consumption from animal products, such as liquid egg and egg powder must fulfill quality assurance, based on food security. The specialized sector to develop

Recebido em 14 de junho de 2016

Aceito em 6 de janeiro de 2017

E-mail:siaq06@hotmail.com safer and quick cooking products derived through the use of modern technology - the egg products. Egg products are products resulting from the processing of eggs, or of various components or mixtures of eggs, or from the further processing of such processed products (Commission, 2004). The industrialization of 
powdered eggs provides economic benefits and extending the useful life of the product, in transportation and storage facilities. Increasingly they are used in preparations and hospital diets, where food safety should be monitored with greater rigidity (Bourre and Galea, 2006). The egg powder has an average of $47.3 \%$ protein, and has high biological value and was considered by the Food and Agriculture Organization (FAO) of United Nations and World Health Organization (WHO) the protein standard, in essential amino acid composition (FAO, 1971). The supply of food has increased dramatically, fueled by increasingly capital-intensive agriculture, continuing application of biological/genetic science to food production, greater ability to save crops from pests, and greater ability to preserve perishable products during transport (Deloitte, 2013). However, according to Food, Drug and Administration (FDA) food at all stages of production is susceptible to contamination. The source of food is important because pathogenic microorganisms may be present in the breeding stock of farm animals, in feeds, in the farm environment and others (Food, 2009). The risks of contamination of raw material exists also to new products derived from fresh eggs, as powered eggs, that are growing in the wholesale and retail market, but the raw material still follows the traditional pasteurization system in the production chain, which only serves to reduce the microbial load in their vegetative form, not including sterilization of the final product (Franco and Landgraf, 2002).

Many studies pointed out the contamination by bacteria such as Escherichia coli, Salmonella spp. and Pseudomonas spp. in poultry farms, causing great economic losses and associating the decrease in internal egg quality during storage, caused by the presence of other Staphylococcus species, Enterobacter spp. and also others mesophilic microorganisms (Chaemsanit et al., 2015). On the other hand, there are few studies that associate the fungal contamination with fresh eggs and, moreover, there are no reference standards for fungi counts (yeasts and molds) in fresh eggs (in nature) and their derivatives products in the Brazilian laws. Andrade et al. (2004) pointed out the worrying contamination by fungi of the genus Aspergillus in eggs in nature in $5.36 \%$ of samples. Some species of this genus produce mycotoxins and can cause damage to human health when ingested in food. Food irradiation is one of the methods of preservation most extensively studied and widely. Equipments, decontamination and sterilization techniques of food are every day becoming more efficient and accessible for the safety and contributing to a healthier diet for the population (Aquino, 2011).

Therefore, the focus of this study was to analyze the decontamination effects of gamma radiation using doses of 5 kilograys (kGy) and $10 \mathrm{kGy}$ to control fungi and bacteria in 60 commercial samples of egg white, yolk and whole egg powder and evaluated the microbiological quality of these products in a dehydrated form, acquired in the wholesale trade of São Paulo city, in Brazil. The ionizing radiation provides a radiation treatment which consists of the exposing the finished products to gamma rays, which are electromagnetic waves with high energy, using a cobalt 60 source. The energy of the ionizing radiation directly affects the DNA molecules, causing damages in the fungi and bacteria cells (known as direct effect). Another form of damage is the so-called indirect effect of radiation, which consists in the interaction of ionizing radiation with water molecules present into the microbe cell or around the substrate, producing free radicals and ions that affect the DNA of the microorganism (Aquino, 2011).

\section{MATERIALS AND METHODS}

The commercial samples of egg white, yolk and whole egg powder, respectively, were acquired in the amount of 60 samples with 3 kilograms (kg) each, in the wholesale trade of São Paulo city. The samples of each product (20 for egg white, 20 yolk and 20 whole egg powder) were fractionated in a number of 10 subsamples containing 100 grams (g) and were divided into three groups: non-irradiated (control group), the group treated with $5 \mathrm{kGy}$ and the group treated with $10 \mathrm{kGy}$. Each subsample that were placed in triplicate in sterile polyethylene bags, previously irradiated at a dose of $20 \mathrm{kGy}$. The samples were subjected to the process of ionizing radiation (gamma rays) at a dose of $5 \mathrm{kGy}$ and $10 \mathrm{kGy}$, at the Instituto de Pesquisas Energéticas e Nucleares (IPEN/ CNEN - USP), located in São Paulo city. It was used a Multipurpose irradiator containing a cobalt 60 source with activity of 40 TBq or $10^{6} \mathrm{Ci}$, at a dose rate $3 \mathrm{kGy}$ per hour at a temperature of $25^{\circ} \mathrm{C}( \pm 2)$. 
For the bacteriological and fungal analysis it was carried out a total count of total coliforms and fecal coliforms, molds and yeasts, Salmonella spp. and Staphylococcus aureus, using the technique of Most Probable Number (MPN) in triplicate. The number of positive and negative tubes in different dilutions using standards tables for detecting the MNP (Silva, 2002; Silva et al., 2007). A rate of $25 \mathrm{~g}$ of each subsamples were taken for preparation of the first dilution $\left(10^{-1}\right)$ in $225 \mathrm{~mL}$ of peptonated buffered water $0.1 \%$, and subsequent preparations of decimal dilutions were performed in tubes containing $9 \mathrm{~mL}$ of the same diluent to obtain concentrations of $10^{-2}$ and $10^{-3}$. For the research coliforms, fermentation technique was used in multiple tubes, initially being performed presumptive test using broth lauryl sulfate tryptose (LST) for incubation of dilutions, remaining this material in an oven to demand biological oxygen (DBO) at $35^{\circ} \mathrm{C}$ for 48 hours. The tubes with positive results was carried out confirmatory test using brilliant green bile broth (GBB) for coliforms at $35^{\circ} \mathrm{C}$ and the broth Escherichia coli (EC) to $45^{\circ} \mathrm{C}$.

In order to identification the fungal genera, it was adopted the surface plating method and a serial dilutions carried out until $10^{-10}$ Potato Dextrose Agar (ABD) in triplicate into Petri dishes, using $10 \mathrm{~g}$ of each subsample. The dishes were incubated at $25^{\circ} \mathrm{C}\left( \pm 2^{\circ} \mathrm{C}\right)$ until the development of mycelium after 7 to 10 days. For microscopic observation it was used the technique of direct mycological examination under light microscope glass slide containing a drop of blue cotton lactophenol and employment of the microculture technique. The identification of fungi was carried out according to macroscopic and microscopic descriptive criteria, based on the appropriate keys described by Pitt and Hocking (2009).

The physicochemical determinations were carried out in triplicate. Physicochemical analyses for $\mathrm{pH}$ and humidity were performed using the Instituto Adolfo Lutz method (Zenebon et al., 2005) and the water activity $(A w)$ was determined using AQUALAB equipment (Decagon) of Laboratório de Micotoxinas at the Instituto de Ciências Biomédicas II (USP). Samples of $3 \pm 1.0 \mathrm{~g}$ were analyzed at controlled temperature of $26.0 \pm 0.5^{\circ} \mathrm{C}$. The statistic analysis of data was perfomed using the Statistical
Package for Social Science (SPSS) for Windows 16, 2007.

\section{RESULTS AND DISCUSSION}

The official parameters of maximum humidity of $4 \%$ to whole egg powder and powder yolk, and the value of $8 \%$ humidity to white egg powder is considered the maximum to ensure the properties of dry material, above this value the product stability may be compromised, according to Brazilian standards (Brasil, 2000). According to Min et al. (2012) the $\mathrm{pH}$ of irradiated and nonirradiated egg white was around $\mathrm{pH}$ 9.0, which was higher than that of the newly laid eggs. The $A w$ would be defined as the free water available in the substrate for microbial metabolism. The most foods have $A w$ above 0.95 and that will provide sufficient moisture to support the growth of bacteria, yeasts, and mould. The amount of available moisture can be reduced to a point which will inhibit the growth of the microorganisms. The main objective of drying is to decrease the $A w$ of various perishable materials to values $<0.5$, in order to enable their storage at ambient temperature. The importance of $A w$ in controlling the shelf-life of foods by suppressing the growth of microorganisms, by reducing the rates of chemical reactions, and by inhibiting enzymatic deterioration is well established (Bonazzi and Dumoulin, 2011)

The $A w$ of food is controlled to 0.85 or less in the finished product, according to Food and Drug Administration (2015), as an example of dry milk with $8 \%$ of total moisture and $A w$ of 0.70 . Besides, in food products the shelf life is directly related not only to factors such as temperature, exposure to light and oxygen, as well as the $A w$, which would be defined as the free water available in the substrate for microbial metabolism.

The humidity, $A w$ and $\mathrm{pH}$ of all products of control group showed a lower limit observed for dehydrated products through this process, within a margin of safety (Table 1). The results indicated that the value of $A w$ for yolk, egg white and whole egg powder was consistent with the dehydrated products and below the minimum value that favors degradative reactions, with a decreasing according to the dose, in all samples irradiated with the dose of $5 \mathrm{kGy}$ and $10 \mathrm{kGy}$. 
Aquino et al.

Table 1. Physicochemical analysis of irradiated and non-irradtiated (control) samples of white egg powder

\begin{tabular}{clllllllll} 
& & \multicolumn{2}{c}{ Control } & \multicolumn{3}{c}{$5 \mathrm{kGy}$} & \multicolumn{3}{c}{$10 \mathrm{kGy}$} \\
& Hum & $A w$ & $\mathrm{pH}$ & Hum & $A w$ & $\mathrm{pH}$ & Hum & $A w$ & $\mathrm{pH}$ \\
\hline 1 & 6.4 & 0.56 & 9.0 & 6.0 & 0.52 & 9.2 & 5.9 & 0.42 & 9.2 \\
2 & 7.0 & 0.52 & 9.2 & 6.4 & 0.48 & 9.1 & 6.1 & 0.43 & 9.2 \\
3 & 6.8 & 0.56 & 9.2 & 6.6 & 0.51 & 9.0 & 6.0 & 0.45 & 8.9 \\
4 & 6.9 & 0.57 & 8.6 & 6.6 & 0.53 & 8.2 & 6.0 & 0.49 & 8.8 \\
5 & 7.4 & 0.54 & 9.2 & 6.7 & 0.52 & 9.5 & 7.2 & 0.48 & 9.1 \\
6 & 6.9 & 0.55 & 9.5 & 6.0 & 0.49 & 9.3 & 5.8 & 0.47 & 9.1 \\
7 & 7.3 & 0.57 & 9.1 & 7.1 & 0.50 & 9.7 & 6.9 & 0.49 & 9.5 \\
8 & 7.2 & 0.56 & 7.9 & 6.8 & 0.51 & 7.9 & 6.4 & 0.42 & 7.6 \\
9 & 6.9 & 0.54 & 8.8 & 6.6 & 0.48 & 8.9 & 6.2 & 0.43 & 9.0 \\
10 & 7.3 & 0.56 & 8.7 & 7.0 & 0.52 & 9.0 & 6.7 & 0.46 & 8.9 \\
\hline SD & 0.327448 & 0.025841 & 0.316403 & 0.207900 & 0.207900 & 0.354181 & 0.216025 & 0.016633 & 0.473756
\end{tabular}

References values (Brasil, 2000): Humidity maximum 4\%; pH 6.0 - 7.0. SD - Standard Deviation

The results of white egg powder samples showed significant differences in the humidity and $A w$ values $(\mathrm{p}<0.05)$. It was observed that the control group and $5 \mathrm{kGy}$ showed significant differences $(\mathrm{p}=0.000313)$ in humidity values, as well as the control group and $10 \mathrm{kGy}(\mathrm{p}=0.002)$. The $A w$ decrease was also observed comparing the control group and $5 \mathrm{kGy}(\mathrm{p}=0.0003)$ as well as control group and $10 \mathrm{kGy}(\mathrm{p}=0.000009)$. According to Aquino et al. (2010) after the irradiation process the $A w$ decreased as an effect of gamma radiation, due to the indirect effects of radiolysis. The same authors observed the significant decrease $(\mathrm{p}<0.05)$ of $A w$ values of irradiated medicinal herbs, with $5 \mathrm{kGy}$ and 10 $\mathrm{kGy}$. The treatment of gamma radiation showed no significant differences to the $\mathrm{pH}$ values to the control group and $5 \mathrm{kGy}(\mathrm{p}=0.847)$ and to the control and $10 \mathrm{kGy}(\mathrm{p}=0.270)$.
There is no significant difference between the control group of powder yolk and $5 \mathrm{kGy}$ $(\mathrm{p}=0.641553)$ as well as the control group and 10 $\mathrm{kGy}(\mathrm{p}=0.159)$ to humidity values, instead of $A w$ values that showed significant difference between control and $5 \mathrm{kGy}(\mathrm{p}=0.0002)$ and the control and $10 \mathrm{kGy}(\mathrm{p}=0.000001)$. The treatment of $5 \mathrm{kGy}$ showed a significant difference for the $\mathrm{pH}$ values when compared to the control group $(p=0.000031)$ and for the control and $10 \mathrm{kGy}$ $(\mathrm{p}=0.000151)$ as demonstrated in Table 2 .

For the whole egg powder (Table 3), the effects of gamma radiation were similar to white egg powder, with a decrease in humidity and $A w$ values $(\mathrm{p}<0.05)$ and did not present a significant difference in the $\mathrm{pH}$ values for the control group when compared with $5 \mathrm{kGy}$ and $10 \mathrm{kGy}$ $(\mathrm{p}>0.05)$.

Table 2. Physicochemical analysis of irradiated and non-irradtiated (control) samples of powder yolk

\begin{tabular}{cccccccccc}
\hline & \multicolumn{3}{c}{ Control } & \multicolumn{3}{c}{$5 \mathrm{kGy}$} & \multicolumn{4}{c}{$10 \mathrm{kGy}$} \\
& Hum & $A w$ & $\mathrm{pH}$ & Hum & $A w$ & $\mathrm{pH}$ & Hum & $A w$ & $\mathrm{pH}$ \\
\hline 1 & 2.3 & 0.50 & 6.7 & 2.7 & 0.47 & 6.2 & 2.9 & 0.44 & 6.0 \\
2 & 3.0 & 0.52 & 6.2 & 3.2 & 0.49 & 6.1 & 2.8 & 0.44 & 6.0 \\
3 & 2.8 & 0.56 & 6.1 & 3.1 & 0.50 & 7.0 & 2.6 & 0.46 & 6.9 \\
4 & 2.9 & 0.57 & 7.0 & 2.9 & 0.47 & 7.0 & 2.9 & 0.43 & 7.0 \\
5 & 3.4 & 0.54 & 7.1 & 2.4 & 0.48 & 6.9 & 2.4 & 0.46 & 7.2 \\
6 & 3.5 & 0.55 & 6.7 & 3.1 & 0.48 & 6.5 & 2.8 & 0.48 & 6.6 \\
7 & 4.0 & 0.57 & 6.7 & 3.4 & 0.45 & 6.9 & 2.6 & 0.47 & 6.8 \\
8 & 3.0 & 0.56 & 6.4 & 2.9 & 0.50 & 6.8 & 2.3 & 0.43 & 6.8 \\
9 & 2.3 & 0.54 & 6.8 & 2.6 & 0.44 & 6.5 & 2.8 & 0.44 & 6.6 \\
10 & 2.9 & 0.56 & 7.1 & 3.1 & 0.49 & 7.0 & 2.9 & 0.45 & 7.1 \\
\hline SD & 0.521643 & 0.022632 & 0.352136 & 0.302581 & 0.017029 & 0.354181 & 0.216025 & 0.016633 & 0.473756 \\
\hline
\end{tabular}

References values (Brasil, 2000): Humidity maximum 4\%; pH 6.0 - 7.0. SD = Standard Deviation 
Table 3. Physicochemical analysis of irradiated and non-irradtiated (control) samples of whole egg powder

\begin{tabular}{clllllllll}
\hline & \multicolumn{3}{c}{ Control } & \multicolumn{3}{c}{$5 \mathrm{kGy}$} & \multicolumn{3}{c}{$10 \mathrm{kGy}$} \\
& Hum & $A w$ & $\mathrm{pH}$ & Hum & $A w$ & $\mathrm{pH}$ & Hum & $A w$ & $\mathrm{pH}$ \\
\hline 1 & 3.2 & 0.52 & 8.3 & 3.0 & 0.48 & 8.2 & 2.9 & 0.45 & 8.1 \\
2 & 3.0 & 0.55 & 7.9 & 2.4 & 0.50 & 8.1 & 2.8 & 0.44 & 8.0 \\
3 & 3.8 & 0.57 & 7.6 & 2.9 & 0.53 & 7.9 & 2,6 & 0.46 & 7.6 \\
4 & 2.9 & 0.49 & 7.8 & 2.6 & 0.50 & 7.6 & 2.9 & 0.45 & 7.2 \\
5 & 3.4 & 0.51 & 7.9 & 2.7 & 0.49 & 7.4 & 2.4 & 0.43 & 7.2 \\
6 & 3.7 & 0.56 & 8.4 & 3.0 & 0.52 & 8.0 & 2.8 & 0.42 & 8.4 \\
7 & 3.2 & 0.52 & 8.3 & 2.9 & 0.48 & 8.7 & 2.6 & 0.47 & 8.5 \\
8 & 3.8 & 0.54 & 7.7 & 2.8 & 0.49 & 7.9 & 2.3 & 0.43 & 7.6 \\
9 & 3.4 & 0.56 & 7.9 & 2.6 & 0.50 & 8.1 & 2.8 & 0.44 & 8.3 \\
10 & 3.1 & 0.55 & 8.5 & 3.0 & 0.48 & 8.2 & 2.9 & 0.42 & 8.1 \\
\hline SD & 0.327448 & 0.025841 & 0.316403 & 0.207900 & 0.017029 & 0.354181 & 0.216025 & 0.016633 & 0.473756
\end{tabular}

References values (Brasil, 2000): Humidity maximum 4\%; pH 6.0 - 7.0. SD - Standard Deviation

According to Brazilian legislation (Brasil, 2000) the total count limit $\left(<5 \times 10^{3} \mathrm{CFU} / \mathrm{g}\right)$, coliforms $35^{\circ} \mathrm{C} \quad(<10 \mathrm{MPN} / \mathrm{g})$ and coliforms $45^{\circ} \mathrm{C}$ $(<0.3 \mathrm{MPN} / \mathrm{g})$, were considered safety in all control group analyzed (Table 4, 5 and 6).

The treatment with the dose of $5 \mathrm{kGy}$ and 10 kGy demonstrated that the gamma radiation process eliminated the bacteriological burden of all samples of white egg powder (Table 4). Gram negative are typically more sensitive to ionizing radiation than Gram positive bacteria such as Staphylococcus (Monk et al., 1995).

Staphylococcus aureus and Salmonella spp. were absent in $25 \mathrm{~g}$ of all products, as demand our legislation. It was not observed the presence of bacteria in all irradiated products (Table 4, 5 and $6)$. The results corroborate the findings of Rowley et al. (1974), which observed that for the complete elimination of pathogens such as Salmonella spp. it were necessary doses around 5 to $10 \mathrm{kGy}$.

Table 4. Bacteriological analysis of irradiated group and non-irradtiated group of white egg powder

\begin{tabular}{|c|c|c|c|c|c|c|c|c|c|}
\hline \multirow[b]{2}{*}{ Subsamples } & \multicolumn{3}{|c|}{ Control } & \multicolumn{3}{|c|}{$5 \mathrm{kGy}$} & \multicolumn{3}{|c|}{$10 \mathrm{kGy}$} \\
\hline & $\begin{array}{c}\text { Total } \\
\text { count } \\
(\mathrm{CFU} / \mathrm{g})\end{array}$ & $\begin{array}{c}\text { Coli. } \\
35^{\circ} \mathrm{C} \\
\text { MPN/g }\end{array}$ & $\begin{array}{c}\text { Coli. } \\
45^{\circ} \mathrm{C} \\
\mathrm{MPN} / \mathrm{g}\end{array}$ & $\begin{array}{c}\text { Total } \\
\text { count } \\
(\mathrm{CFU} / \mathrm{g})\end{array}$ & $\begin{array}{c}\text { Coli. } \\
35^{\circ} \mathrm{C} \\
\text { MPN/g }\end{array}$ & $\begin{array}{c}\text { Coli. } \\
45^{\circ} \mathrm{C} \\
\text { MPN/g }\end{array}$ & $\begin{array}{c}\text { Total } \\
\text { count } \\
(\mathrm{CFU} / \mathrm{g})\end{array}$ & $\begin{array}{c}\text { Coli. } \\
35^{\circ} \mathrm{C} \\
\text { MPN/g }\end{array}$ & $\begin{array}{c}\text { Coli. } \\
45^{\circ} \mathrm{C} \\
\mathrm{MPN} / \mathrm{g}\end{array}$ \\
\hline 1 & $1.4 \times 10^{3}$ & 1.0 & $<0.3$ & ND & ND & ND & ND & ND & ND \\
\hline 2 & $3.2 \times 10^{2}$ & 2.6 & $<0.3$ & ND & ND & ND & ND & ND & ND \\
\hline 3 & $2.4 \times 10^{1}$ & 1.4 & $<0.3$ & ND & ND & ND & ND & ND & ND \\
\hline 4 & $1.5 \times 10^{3}$ & 1.2 & $<0.3$ & ND & ND & ND & ND & ND & ND \\
\hline 5 & $5.7 \times 10^{2}$ & 3.0 & $<0.3$ & ND & ND & ND & ND & ND & ND \\
\hline 6 & $2.0 \times 10^{2}$ & 2.3 & $<0.3$ & ND & ND & ND & ND & ND & ND \\
\hline 7 & $7.1 \times 10^{1}$ & 3.6 & $<0.3$ & ND & ND & ND & ND & ND & ND \\
\hline 8 & $3.3 \times 10^{2}$ & 1.7 & $<0.3$ & ND & ND & ND & ND & ND & ND \\
\hline 9 & $1.5 \times 10^{3}$ & 2.1 & $<0.3$ & ND & ND & ND & ND & ND & ND \\
\hline 10 & $2.0 \times 10^{2}$ & 2.4 & $<0.3$ & ND & ND & ND & ND & ND & ND \\
\hline
\end{tabular}

Coli. - Coliforms; MPN - Most Probable Number; CFU - Colony Forminig Units; ND- Not Detected 
Table 5. Bacteriological analysis of irradiated group and non-irradtiated group of powder yolk

\begin{tabular}{|c|c|c|c|c|c|c|c|c|c|}
\hline \multirow[b]{2}{*}{ Subsamples } & \multicolumn{3}{|c|}{ Control } & \multicolumn{3}{|c|}{$5 \mathrm{kGy}$} & \multicolumn{3}{|c|}{$10 \mathrm{kGy}$} \\
\hline & $\begin{array}{c}\text { Total } \\
\text { count } \\
(\mathrm{CFU} / \mathrm{g})\end{array}$ & $\begin{array}{c}\text { Coli. } \\
35^{\circ} \mathrm{C} \\
\text { MPN/g }\end{array}$ & $\begin{array}{c}\text { Coli. } \\
45^{\circ} \mathrm{C} \\
\text { MPN/g }\end{array}$ & $\begin{array}{c}\text { Total } \\
\text { count } \\
(\mathrm{CFU} / \mathrm{g})\end{array}$ & $\begin{array}{c}\text { Coli. } \\
35^{\circ} \mathrm{C} \\
\mathrm{MPN} / \mathrm{g}\end{array}$ & $\begin{array}{c}\text { Coli. } \\
45^{\circ} \mathrm{C} \\
\mathrm{MPN} / \mathrm{g} \\
\end{array}$ & $\begin{array}{c}\text { Total } \\
\text { count } \\
(\mathrm{CFU} / \mathrm{g})\end{array}$ & $\begin{array}{c}\text { Coli. } \\
35^{\circ} \mathrm{C} \\
\text { MPN/g }\end{array}$ & $\begin{array}{c}\text { Coli. } \\
45^{\circ} \mathrm{C} \\
\mathrm{MPN} / \mathrm{g} \\
\end{array}$ \\
\hline 1 & $1.7 \times 10^{3}$ & 2.8 & $<0.3$ & ND & ND & ND & ND & ND & ND \\
\hline 2 & $2.2 \times 10^{2}$ & 1.7 & $<0.3$ & ND & ND & ND & ND & ND & ND \\
\hline 3 & $2.7 \times 10^{2}$ & 1.3 & $<0.3$ & ND & ND & ND & ND & ND & ND \\
\hline 4 & $6.0 \times 10^{2}$ & 3.2 & $<0.3$ & ND & ND & ND & ND & ND & ND \\
\hline 5 & $2.9 \times 10^{2}$ & 2.0 & $<0.3$ & ND & ND & ND & ND & ND & ND \\
\hline 6 & $1.5 \times 10^{2}$ & 1.1 & $<0.3$ & ND & ND & ND & ND & ND & ND \\
\hline 7 & $7.0 \times 10^{1}$ & 3.6 & $<0.3$ & ND & ND & ND & ND & ND & ND \\
\hline 8 & $4.3 \times 10^{2}$ & 3.9 & $<0.3$ & ND & ND & ND & ND & ND & ND \\
\hline 9 & $3.5 \times 10^{3}$ & 2.0 & $<0.3$ & ND & ND & ND & ND & ND & ND \\
\hline 10 & $6.9 \times 10^{2}$ & 3.8 & $<0.3$ & ND & ND & ND & ND & ND & ND \\
\hline
\end{tabular}

Coli. - Coliforms; MPN - Most Probable Number; CFU - Colony Forminig Units; ND- Not Detected

Table 6. Bacteriological analysis of irradiated and non-irradtiated (control) samples of whole egg powder

\begin{tabular}{|c|c|c|c|c|c|c|c|c|c|}
\hline \multirow[b]{2}{*}{ Subsamples } & \multicolumn{3}{|c|}{ Control } & \multicolumn{3}{|c|}{$5 \mathrm{kGy}$} & \multicolumn{3}{|c|}{$10 \mathrm{kGy}$} \\
\hline & $\begin{array}{c}\text { Total } \\
\text { count } \\
\text { (CFU/g) }\end{array}$ & $\begin{array}{c}\text { Coli. } \\
35^{\circ} \mathrm{C} \\
\mathrm{MPN} / \mathrm{g}\end{array}$ & $\begin{array}{c}\text { Coli. } \\
45^{\circ} \mathrm{C} \\
\mathrm{MPN} / \mathrm{g}\end{array}$ & $\begin{array}{c}\text { Total } \\
\text { count } \\
(\mathrm{CFU} / \mathrm{g})\end{array}$ & $\begin{array}{c}\text { Coli. } \\
35^{\circ} \mathrm{C} \\
\text { MPN/g }\end{array}$ & $\begin{array}{c}\text { Coli. } \\
45^{\circ} \mathrm{C} \\
\mathrm{MPN} / \mathrm{g}\end{array}$ & $\begin{array}{c}\text { Total } \\
\text { count } \\
\text { (CFU/g) }\end{array}$ & $\begin{array}{c}\text { Coli. } \\
35^{\circ} \mathrm{C} \\
\text { MPN/g }\end{array}$ & $\begin{array}{c}\text { Coli. } \\
45^{\circ} \mathrm{C} \\
\mathrm{MPN} / \mathrm{g}\end{array}$ \\
\hline 1 & $3.8 \times 10^{3}$ & 2.1 & $<0.3$ & ND & ND & ND & ND & ND & ND \\
\hline 2 & $4.1 \times 10^{3}$ & 2.6 & $<0.3$ & ND & ND & ND & ND & ND & ND \\
\hline 3 & $1.8 \times 10^{3}$ & 1.3 & $<0.3$ & ND & ND & ND & ND & ND & ND \\
\hline 4 & $2.3 \times 10^{3}$ & 1.7 & $<0.3$ & ND & ND & ND & ND & ND & ND \\
\hline 5 & $3.3 \times 10^{3}$ & 1.8 & $<0.3$ & ND & ND & ND & ND & ND & ND \\
\hline 6 & $6.0 \times 10^{2}$ & 3.8 & $<0.3$ & ND & ND & ND & ND & ND & ND \\
\hline 7 & $8.3 \times 10^{1}$ & 3.7 & $<0.3$ & ND & ND & ND & ND & ND & ND \\
\hline 8 & $2.3 \times 10^{3}$ & 2.3 & $<0.3$ & ND & ND & ND & ND & ND & ND \\
\hline 9 & $4.1 \times 10^{3}$ & 3.5 & $<0.3$ & ND & ND & ND & ND & ND & ND \\
\hline 10 & $7.0 \times 10^{2}$ & 4.5 & $<0.3$ & ND & ND & ND & ND & ND & ND \\
\hline
\end{tabular}

Coli. - Coliforms; MPN - Most Probable Number; CFU - Colony Forminig Units; ND- Not Detected

Bacteria and fungi are main microorganisms responsible for the physical and chemical changes observed in the eggs after laying (Lacerda, 2011). According to GiampietroGaneco et al. (2015) an assessment of the internal quality attributes of eggs associated with the storage form is indispensable and after oviposition, eggs inevitably begin to undergo structural changes which can lead to a loss of quality and eventually deterioration. According to Stringhini et al. (2009), the reduction of environmental contamination of equipment and facilities on farms could reduce by $80 \%$ the bacterial contamination in final production of eggs. In this scenario, even adopting the Good Manufacturing Practices (GMP) during the eggs fresh production and considering that the raw material for the preparation of products derived from eggs undergo a pasteurization process, the presence of airborne fungi indicates the need for monitoring of air quality in industries and greater selection and quality control of eggs coming from selected farms.

According to European Regulation the total limit for the liquid whole egg and yolk to filamentous fungi and yeasts count is below $1.5 \times 10^{3} \mathrm{CFU} / \mathrm{g}$ (Commission..., 2004). There is no limit or determination to fungi counts in egg samples in Brazil and the present study based on the EC $n^{\circ}$ 853 threshold for the processed egg product as a parameter, it was observed in the present study that $50 \%$ of samples of whole egg powder were above the limit values stipulated by European Regulation. 
The results of fungal counting showed that five samples of whole egg powder, one of white egg powder and four egg yolk powder were above the limits of Regulation EC $\mathrm{n}^{\circ} 853$ (Commission..., 2014), as demonstrated in Table 7, 8 and 9 (in bold). After the irradiation treatment, with the doses of $5 \mathrm{kGy}$ and $10 \mathrm{kGy}$, all samples were within the limits or undetectable for fungi. The white egg powder samples that were above the EC limit were $10 \%$ and the yolk powder samples were $30 \%$ (Table 8 and Table 9).

The irradiated samples with $5 \mathrm{kGy}$ dose showed a reduction in fungal load at $80 \%$ of whole egg powder samples (Table 7) and $90 \%$ of egg white powder and powdered yolk (Table 8 and Table 9), this result is due to the lower bioburden in the egg white and powdered yolk samples of control group.

Table 7. Fungi counting (CFU/g) in control samples of whole egg powder

\begin{tabular}{|c|c|c|c|c|c|}
\hline \multirow[b]{2}{*}{ Subsamples } & \multicolumn{2}{|c|}{ Control } & \multicolumn{2}{|c|}{$5 \mathrm{kGy}$} & \multirow{2}{*}{$\begin{array}{l}10 \mathrm{kGy} \\
\text { Genus } \\
\text { CFU/g }\end{array}$} \\
\hline & Genus & $\mathrm{CFU} / \mathrm{g}$ & Genus & $\mathrm{CFU} / \mathrm{g}$ & \\
\hline 1 & $\begin{array}{c}\text { Aspergillus spp. } \\
\text { Penicillium spp. } \\
\text { Trichoderma spp. } \\
\text { Yeasts }\end{array}$ & $\begin{array}{l}5 \times 10^{2} \\
6 \times 10^{2} \\
4 \times 10^{2} \\
1 \times 10^{1}\end{array}$ & ND & ND & ND \\
\hline 2 & $\begin{array}{l}\text { Bipolaris spp.* } \\
\text { Cladosporium spp. } \\
\text { Penicillium spp. } \\
\text { Aspergillus spp. }\end{array}$ & $\begin{array}{l}2 \times \mathbf{1 0}^{3} \\
4 \times 10^{2} \\
2 \times 10^{2} \\
3 \times 10^{2}\end{array}$ & ND & ND & ND \\
\hline 3 & $\begin{array}{l}\text { Cladosporium spp. } \\
\text { Yeasts* }\end{array}$ & $\begin{array}{l}1 \times 10^{2} \\
\mathbf{4} \times \mathbf{1 0}^{3}\end{array}$ & ND & ND & ND \\
\hline 4 & $\begin{array}{l}\text { Cladosporium spp. } \\
\text { Penicillium spp. }\end{array}$ & $\begin{array}{l}3 \times 10^{2} \\
3 \times 10^{2}\end{array}$ & ND & ND & ND \\
\hline 5 & $\begin{array}{c}\text { Cladosporium spp. } \\
\text { NSF* } \\
\text { Yeasts }\end{array}$ & $\begin{array}{l}2 \times 10^{2} \\
\mathbf{2} \times \mathbf{1 0}^{3} \\
1 \times 10^{3}\end{array}$ & ND & ND & ND \\
\hline 6 & $\begin{array}{l}\text { Nigrospora spp.* } \\
\text { Cladosporium spp. } \\
\text { Penicillium spp. } \\
\text { Aspergillus spp. }\end{array}$ & $\begin{array}{l}5 \times \mathbf{1 0}^{3} \\
2 \times 10^{2} \\
2 \times 10^{2} \\
1 \times 10^{2}\end{array}$ & Nigrospora spp. & $1 \times 10^{2}$ & ND \\
\hline 7 & $\begin{array}{l}\text { Cladosporium spp. } \\
\text { Penicillium spp. }\end{array}$ & $\begin{array}{l}2 \times 10^{2} \\
3 \times 10^{2}\end{array}$ & ND & ND & ND \\
\hline 8 & $\begin{array}{c}\text { NSF } \\
\text { Penicillium spp. }\end{array}$ & $\begin{array}{l}4 \times 10^{2} \\
1 \times 10^{3}\end{array}$ & ND & ND & ND \\
\hline 9 & $\begin{array}{l}\text { Cladosporium spp. } \\
\text { Penicillium spp. } \\
\text { Yeasts }\end{array}$ & $\begin{array}{l}6 \times 10^{2} \\
3 \times 10^{2} \\
3 \times 10^{2}\end{array}$ & ND & ND & ND \\
\hline 10 & $\begin{array}{c}\text { Alternaria spp.* } \\
\text { Cladosporium spp. } \\
\text { Yeasts }\end{array}$ & $\begin{array}{l}2 \times \mathbf{1 0}^{\mathbf{3}} \\
1 \times 10^{2} \\
5 \times 10^{2}\end{array}$ & Alternaria spp. & $2 \times 10^{1}$ & ND \\
\hline
\end{tabular}

*Maximum fungal limit in Regulation (EC) $\mathrm{n}^{\circ} 853$ (Commission..., 2004) - 1.5 x 10 $0^{3} \mathrm{CFU} / \mathrm{g}$ 
Aquino et al.

Table 8. Fungi counting (CFU/g) in control samples of white egg powder

\begin{tabular}{cccccc}
\hline \multirow{2}{*}{ Subsamples Control } & \multicolumn{2}{c}{$5 \mathrm{kGy}$} & & $10 \mathrm{kGy}$ \\
\cline { 2 - 6 } & Genus & CFU/g & Genus & CFU/g & Genus CFU/g \\
\hline \multirow{2}{*}{1} & Penicillium spp. & $1 \times 10^{2}$ & ND & ND & ND \\
& NSF & $5 \times 10^{1}$ & & & \\
2 & Penicillium spp. & $2 \times 10^{2}$ & ND & ND & ND \\
3 & Cladosporium spp. & $4 \times 10^{2}$ & & & ND \\
4 & Aspergillus spp. & $6 \times 10^{2}$ & Aspergillus spp. & $5 \times 10^{1}$ & ND \\
5 & NSF & $4 \times 10^{2}$ & ND & ND & ND \\
6 & Cladosporium spp.* & $\mathbf{2} \times \mathbf{1 0}^{3}$ & ND & ND & ND \\
7 & Yeasts & $2 \times 10^{1}$ & ND & ND & ND \\
8 & Cladosporium spp. & $4 \times 10^{2}$ & ND & ND & ND \\
9 & Yeasts & $6 \times 10^{2}$ & ND & ND & ND \\
10 & Yeasts & $3 \times 10^{1}$ & ND & ND & ND \\
\hline
\end{tabular}

*Maximum fungal limit in Regulation (EC) $n^{\circ} 853$ (Commission..., 2004) - 1.5 x 10 $0^{3}$ CFU/g

Table 9. Fungi counting (CFU/g) in control samples of yolk powder

\begin{tabular}{|c|c|c|c|c|c|}
\hline \multirow[b]{2}{*}{ Subsamples } & \multicolumn{2}{|c|}{ Control } & \multicolumn{2}{|c|}{$5 \mathrm{kGy}$} & \multirow{2}{*}{$\begin{array}{l}10 \mathrm{kGy} \\
\text { Genus } \\
\text { CFU/g }\end{array}$} \\
\hline & Genus & $\mathrm{CFU} / \mathrm{g}$ & Genus & $\mathrm{CFU} / \mathrm{g}$ & \\
\hline 1 & Yeasts & $1 \times 10^{2}$ & ND & ND & ND \\
\hline 2 & $\begin{array}{c}\text { Cladosporium spp. } \\
\text { Penicillium spp. }\end{array}$ & $\begin{array}{l}2 \times 10^{2} \\
3 \times 10^{2}\end{array}$ & ND & ND & ND \\
\hline 3 & Aspergillus spp. & $3 \times 10^{2}$ & ND & ND & ND \\
\hline 4 & Cladosporium spp. & $3 \times 10^{3}$ & ND & ND & ND \\
\hline 5 & NSF & $1 \times 10^{2}$ & ND & ND & ND \\
\hline 6 & $\begin{array}{l}\text { Alternaria spp.* } \\
\text { Penicillium spp. }\end{array}$ & $\begin{array}{l}2 \times \mathbf{1 0}^{\mathbf{3}} \\
1 \times 10^{2}\end{array}$ & ND & ND & ND \\
\hline 7 & ND & ND & ND & ND & ND \\
\hline 8 & $\mathrm{NSF}$ & $1 \times 10^{3}$ & ND & ND & ND \\
\hline 9 & Yeasts* & $3 \times 10^{3}$ & Yeasts & $2 \times 10^{1}$ & ND \\
\hline 10 & Yeasts* & $2 \times 10^{3}$ & ND & ND & ND \\
\hline
\end{tabular}

*Maximum fungal limit in Regulation (EC) $\mathrm{n}^{\circ} 853$ (Commission..., 2004) - $1.5 \times 10^{3} \mathrm{CFU} / \mathrm{g}$

Also fungi are identified as microorganisms responsible for physical or chemical changes that were observed in the eggs after laying (Stringhini et al., 2009). Another problem on the farm eggs are the stored humid environment and the fungi can develop in the skin and penetrate through the pores contaminating the albumen. Their growth results in albumen in its complete gelation, color changes and rupture of the yolk membrane (Smith and Read, 1997). The contamination caused by fungi is affected especially by genera of Penicillium, Sporotrichum, Mucor, Cladosporium and Alternaria (Cardoso et al., 2001).

The effectiveness of radiation dose depends on the following factors: type and species of microorganisms; number of microorganisms (or spores) existing initially and; composition of the food. It is possible that some food components, e.g., proteins, catalase and reducing substances on microorganisms exert a protective action; existence or lack of oxygen; physical state of food during irradiation. The amount of moisture as well as the food temperature exerts a different influence on microorganisms; own factors of microorganisms. The age, the growth temperature, the sporulation, the state (vegetative and sporulating cells) and the difference among strains of the same species can influence the level of sensitivity of the microorganisms (Murano, 1995).

Rowley et al. (1974) found that filamentous fungi (Aspergillus and Penicillium genus) had intermediate resistance to radiation. Braghini et 
al. (2015) reported a high radiation resistance of Alternaria alternata as well as demonstrated by Ferreira-Castro et al. (2007) when the authors irratiated the fungus Fusarium verticillioides in maize. The radioresistance is proportional to the concentration of total lipids in the cell and wall cell of fungi contain appreciable lipid fractions (over 20\%), as in the case of certain Aspergillus species (Harwood and Russell, 1984). Some studies have shown that fungal genera that have the pigment melanin in the wall composition, called black or melanized fungi, are more radioresistant. Dadachova et al. (2007) observed that melanized fungi are dominant in place of the Chernobyl accident and further reported that ionizing radiation could alter the electronic properties of melanin (that acts as an antioxidant), enhancing the growth of melanized fungi, suggesting that the presence of melanin would be beneficial for such fungi. This explains the resistance of fungi Nigrospora spp. and Alternaria spp. in the present study, once they are considered melanized fungi.

Aquino et al. (2010) demonstrated that the fungus Aspergillus flavus, Phoma spp. and Syncephalastrum spp. showed a radioresistance after the ionizing treatment at a dose of $5 \mathrm{kGy}$, in packed herbs stored after 30 days of treatment. An important observation about the mycobiota found in all egg samples is that it was composed of yeasts and filamentous fungi that are dispersed into the environment through the atmospheric air, such as fungi of the genus Aspergillus, Penicillium, Cladosporium, Alternaria and Nigrospora. Airborne fungi are responsible for allergies and respiratory problems in humans (Mezzari et al., 2003). This fact indicates that the air quality in the area where the end products (egg powder products) are packed must be continuously monitored by following the GMPs, after the processing of the egg product in industry.

\section{CONCLUSIONS}

Despite variations in the $\mathrm{pH}, A w$ and humidity results of the control and irradiated samples, the general quality parameters found in all products were within the permitted limits for powdered egg products, according to the Brazilian standards. However, the nutritional and sensory properties of egg products that were irradiated were not evaluated and this is a limitation of the present study and the authors recommend further studies in this regard. The control samples of all powdered eggs products purchased from retail market showed fungal contamination above the international limits regulation and the use of gamma radiation at the dose of $10 \mathrm{kGy}$ ensured bacterial and fungal decontamination of all packaged samples, proving to be an important effect for special diets and that should be adopted by the dehydrated eggs industry, focusing on dietetic products intended for infant consumption or in special hospital diets, for example, for transplant patients. The irradiation after final preparation and packaging of products derived from eggs proved to be a food safety measure. Besides the elimination of fungi and bacteria, this technology has contributed to the increased shelf life of the irradiated products, already in its final package, and without increasing the product temperature, as a food safety measure.

\section{REFERENCES}

ANDRADE, M.A.; CAFÉ, M.B.; JAYME, V.S. et al. Avaliação da qualidade bacteriológica de ovos de galinha comercializados em Goiânia, Goiás, Brasil. Ciênc. Anim. Bras., v.5, p.221-228, 2004.

AQUINO, S. Gamma radiation against toxigenic fungi in food, medicinal and aromatic Herbs. In: MÉNDEZVILAS, A. (Ed.). Science against microbial pathogens: communicating current research and technological advances. Badajoz: Formatex Research Center, 2011. p.272-281.

AQUINO, S.; GONÇALEZ, E.; ROSSI, M.H. et al. Evaluation of fungal burden and aflatoxin presence in packed medicinal plants treated by gamma radiation. J. Food Prot., v.73, p.932-937, 2010.

BONAZZI, C; DUMOULIN, E. Quality changes in food materials as influenced by drying processes. In: TSOTSAS, E.; MUJUMDAR, A.S. (Eds.). Modern drying technology. Weinheim: Wiley-VCH \& Verlag, 2011. p.1.

BOURRE, J.M.; GALEA, F. An important source of omega-3 fatty acids, vitamins $d$ and e, carotenoids, iodine and selenium: a new natural multi-enriched egg. J. Nutr. Health Aging, v.10, p.371-376, 2006.

BRAGHINI, R.; ROCHA, L.O.; POZZI, C.R. et al. Effect of gamma radiation on growth and mycotoxins production of Alternaria alternata. Fungal Genom Biol., v.5, p.1-5, 2015.

BRASIL. Ministério da Saúde. Resolução da Diretoria Colegiada $\mathrm{n}^{\circ} .94$, de 01 de novembro de 2000. Regulamento técnico para rotulagem nutricional obrigatória de alimentos e bebidas embalados. Diário Oficial Seção 1, 212-E, 3 nov. 2000. 
CARDOSO, A.L.S.P.; TESSARI, E.N.C.; CASTRO, A.G.M. et al. Pesquisa de coliformes totais e coliformes fecais analisados em ovos comerciais no laboratório de patologia avícola de descalvado. Arq. Inst. Biol., v.68, p.19-22, 2001.

CHAEMSANIT, S.; AKBAR, A.; ANAL, A.K. Isolation of total aerobic and pathogenic bacteria from table eggs and its contents. Food App. Bios. J., v.3, p.1-9, 2015.

COMMISSION Regulation (EC) N.853, of 29 April, 2004. EU Law and Publications. Available in: $<\mathrm{http}$ ///eur-lex.europa.eu/legalcontent/EN/ALL/?uri=CELEX:32004R0853.>. Accessed in: 21 mai. 2015.

DADACHOVA, E.; BRYAN, R.A.; HUANG, X. et $a l$. Ionizing radiation changes the electronic properties of melanin and enhances the growth of melanized fungi. PLoS One., v.2, p.e457, 2007.

DELLOITE, T.T. The food value chain: a challenge for the next century. 2013. Available in: <http://www2.deloitte.com/content/dam/Deloitte/glob al/Documents/Consumer-

Business/dttl_cb_Food\%20Value\%20Chain_Global\% 20POV.pdf.>. Accessed in: 15 Set. 2016.

FARKAS, J. Principios de la irradiación de alimentos. In: LA IRRADIACION DE ALIMENTOS EN LATINOAMÉRICA. 1985, Lima. Proceedings... Lima: OIEA, 1985, p.11-23.

FERREIRA-CASTRO, F.L.; AQUINO, S. GREINER, R. et al. Effects of gamma radiation on maize samples contaminated with Fusarium verticillioides. Appl. Radiat. Isot., v.65, p.927-933, 2007.

FOOD AND AGRICULTURE ORGANIZATION/WORLD HEALTH ORGANIZATION. Ad Hoc Committee of experts on energy and protein: requirements and recommended intakes. FAO/WHO/PR/71/A, 1971. Available in: <ftp://ftp.fao.org/docrep/fao/ meeting/009/ae906e/ae906e00.pdf.>. Accessed in: 15 Set. 2016.

FOOD and drug administration. Water Activity ( $A w$ in Foods). Inspection Technical guides. FDA, 2015. Available

http://www.fda.gov/ICECI/Inspections/InspectionGuid es/InspectionTechnicalGuides/ucm072916.htm>.

Accessed in: 03 Nov. 2016.

FOOD Code. Annex 3 - Public Health Reasons / Administrative Guidelines. Food. Compliance with food law. chap.3. [s.1.]: FDA 2009. Available in: <http://www.fda.gov/Food/GuidanceRegulation/Retail FoodProtection/FoodCode/ucm189211.htm.> Accessed in: 15 Set. 2016.
FRANCO, B.D.G.M.; LANDGRAF, M. (Eds.). Microbiologia dos alimentos. São Paulo: Atheneu, 2002, 182p.

GIAMPIETRO-GANECO, A.; BORBA, H.; SCATOLINI-SILVA, A.M. et al. Quality assessment of eggs packed under modified atmosphere. Ciênc. Agrotec., v.39, p.82-88, 2015.

HARWOOD, J.L.; RUSSEL, N.J. Distribution of lipids. In: FRIEDMAN (Ed.). Lípids in plants and microbes. New York: Academic Press, 1984.

LACERDA, M.J.R. Microbiologia de ovos comerciais, 2011. Disponível em: <https://portais.ufg.br/up/67/o/semi2011_Maria_Julian a_1c.pdf.> Acessado em: 13 fev. 2015.

MEZZARI, A.; PERIN, C. et al. Os fungos anemófilos e sensibilização em indivíduos atópicos em Porto Alegre, RS. Rev. Assoc. Med. Bras., v.49, p.270-273, 2003.

MIN, B.; NAM, K.C.; JO, C. et al. Irradiation of shell egg on the physicochemical and functional properties of liquid egg white. Poult. Sci., v.91, p.2649-2657, 2012.

MONK, J.D.; BEUCHAT, L.R.; DOYLE, P.M. Irradiation inactivation of food-borne microorganisms. J. Food Prot., v.58, p.197-208, 1995.

MURANO, E.A. Irradiation of fresh meats. Food Technol., v.49, p.52-54, 1995.

PITT, J.I.; HOCKING, A.D. Fungi and food spoilage. New York: Springer Verlag, 2009. [143p.].

ROWLEY, D.B.; ANELLIS, A.; WIERBICKI, E. et al. Status of the radapertization of meats. J. Milk Food Technol., v.2, p.71-111, 1974.

SILVA, M.C. Avaliação da qualidade microbiológica de alimentos com a utilização de metodologias convencionais e do sistema simplate. 2002. $75 f$. Dissertação (Mestrado) - Escola Superior de Agricultura Luiz de Queiroz. Piracicaba, São Paulo, SP.

SILVA, N.; JUNQUEIRA, V.C.A.; SILVEIRA, N.F.A.; TANIWAKI, M.H. et al. Manual de métodos de análise microbiológica de alimentos. 3.ed. São Paulo: Varela, 2007. 624p.

SMITH, S.E.; READ, D.J. Mycorrhizal Symbiosis. 2.ed. San Diego: Academic Press, 1997. 800p.

STRINGHINI, M.L.F.; ANDRADE, M.A.; MESQUITA, A.J. et al. Características bacteriológicas de ovos lavados e não lavados de granjas de produção comercial. Cienc. Anim. Bras., v.10, p.1317-1327, 2009.

ZENEBON, O.; PASCUET, N.S.; TIGLEA, P. (Coords.). Normas analíticas, métodos químicos $e$ físicos para análise de alimentos. 3.ed. São Paulo: IAL, 2005. 